\title{
Assessing the nutritional stress hypothesis: relative influence of diet quantity and quality on seabird productivity
}

\author{
Patrick G. R. Jodice ${ }^{1,8, *}$, Daniel D. Roby ${ }^{1}$, Kathy R. Turco ${ }^{2}$, Robert M. Suryan ${ }^{3,4}$, \\ David B. Irons ${ }^{4}$, John F. Piatt ${ }^{5}$, Michael T. Shultz ${ }^{5}$, David G. Roseneau ${ }^{6}$, \\ Arthur B. Kettle ${ }^{6}$, Jill A. Anthony ${ }^{7}$
}

${ }^{1}$ US Geological Survey, Oregon Cooperative Fish and Wildlife Research Unit, Department of Fisheries and Wildlife, Oregon State University, Corvallis, Oregon 97331, USA

${ }^{2}$ Institute of Marine Science, University of Alaska, Fairbanks, Alaska 99775, USA

${ }^{3}$ US Fish and Wildlife Service, Migratory Bird Management, 1011 East Tudor Road, Anchorage, Alaska 99503, USA

${ }^{4}$ US Geological Survey, Oregon Cooperative Fish and Wildlife Research Unit, Hatfield Marine Science Center, Oregon State University, Newport, Oregon 97365, USA

${ }^{5}$ US Geological Survey, Alaska Science Center, 1011 East Tudor Road, Anchorage, Alaska 99503, USA

${ }^{6}$ US Fish and Wildlife Service, Alaska Maritime National Wildlife Refuge, Homer, Alaska 99603, USA

${ }^{7}$ Department of Molecular Microbiology and Immunology, Johns Hopkins Bloomberg School of Public Health, Baltimore, Maryland 21205, USA

${ }^{8}$ Present address: US Geological Survey, South Carolina Cooperative Fish and Wildlife Research Unit, Clemson University, Clemson, South Carolina 29634, USA

\begin{abstract}
Food availability comprises a complex interaction of factors that integrates abundance, taxonomic composition, accessibility, and quality of the prey base. The relationship between food availability and reproductive performance can be assessed via the nutritional stress (NSH) and junkfood (JFH) hypotheses. With respect to reproductive success, NSH posits that a deficiency in any of the aforementioned metrics can have a deleterious effect on a population via poor reproductive success. JFH, a component of NSH, posits specifically that it is a decline in the quality of food (i.e. energy density and lipid content) that leads to poor reproductive success. We assessed each in relation to reproductive success in a piscivorous seabird, the black-legged kittiwake Rissa tridactyla. We measured productivity, taxonomic composition, frequency, size, and quality of meals delivered to nestlings from 1996 to 1999 at 6 colonies in Alaska, USA, 3 each in Prince William Sound and Lower Cook Inlet. Productivity varied widely among colony-years. Pacific herring Clupea pallasi, sand lance Ammodytes hexapterus, and capelin Mallotus villosus comprised ca. $80 \%$ of the diet among colonyyears, and each was characterized by relatively high energy density. Diet quality for kittiwakes in this region therefore remained uniformly high during this study. Meal delivery rate and meal size were quite variable among colony-years, however, and best explained the variability in productivity. Parent kittiwakes appeared to select prey that were energy dense and that maximized the biomass provisioned to broods. While these results fail to support JFH, they do provide substantial support for $\mathrm{NSH}$.
\end{abstract}

KEY WORDS: Nutritional stress hypothesis · Junk-food hypothesis · Black-legged kittiwake · Diet · Provisioning rate $\cdot$ Productivity $\cdot$ Alaska

\section{INTRODUCTION}

Reproductive success in seabirds is largely dependent on foraging constraints experienced by breeding adults. Hence, a primary factor affecting seabird life histories and population dynamics is the extensive spatial and temporal variability inherent in their food supply (Lack 1968, Ashmole 1971). Cairns (1987) recog- 
nized that food availability for seabirds comprises a complex interaction of factors, including prey abundance, the taxonomic composition of the prey base, prey accessibility, and prey quality (which considers energy density and lipid content). Unfortunately, most investigations of the relationship between food availability and avian breeding biology in general, and seabird breeding biology in particular, typically consider only 1 or 2 of these factors and then only in isolation (Uttley et al. 1994, Broadman 1997). Instead, what is required is an examination of the interactions of prey-related variables, including the energetic composition of food and its interaction with quantity. Such an approach has a much greater opportunity to yield data that will elucidate the biological, ecological, and physiological mechanisms underlying the response in reproductive performance and population dynamics to food limitation (Trites \& Donnelly 2003).

Recently, 2 models have been proposed that provide an appropriate context within which to assess the relationship between food availability and reproductive performance in apex marine predators such as seabirds. The first, more broad-based, model is the nutritional stress hypothesis (NSH). NSH posits that a deficiency in prey abundance, availability, or quality can have a deleterious effect on a population via a decline in individual-based metrics such as reproductive performance, body mass, or adult or juvenile survival (Trites \& Donnelly 2003). The second, more specific, model is the junk-food hypothesis (JFH), which may be viewed as a component of NSH. JFH posits that it is the low lipid content and energy density of particular prey types, and shifts in the relative abundance of these prey types, that negatively affect the physiological condition of individuals, neonatal growth rates, and overall productivity (Rosen \& Trites 2000). Within the context of annual variability in seabird reproductive performance, a field assessment of $\mathrm{NSH}$ and $\mathrm{JFH}$ should therefore consider both the quantity and quality of prey obtained by parents.

We sought to determine whether seabird productivity in the northern Gulf of Alaska was affected broadly by nutritional stress and, more specifically, by prey quality. We assessed the relationship between diet (considering taxonomic composition, prey quantity, and prey quality) and annual productivity in blacklegged kittiwakes Rissa tridactyla at 6 colonies in 2 ecosystems during a $4 \mathrm{yr}$ period. We compared diets of kittiwakes among colonies and years and measured meal delivery rates, mass of meals, and energy density of nestling meals. We assessed the impacts of these 3 parameters, singly and in combination, as well as potential effects of colony, ecosystem, and year on annual productivity using a model selection approach (Burnham \& Anderson 1998). By including data on multiple metrics of diet composition, we were able to undertake a thorough investigation of the possible role that food quantity and quality played in the dynamics of seabird populations. These data represent one of the broadest examinations of $\mathrm{NSH}$ and $\mathrm{JFH}$ in a seabird system.

\section{MATERIALS AND METHODS}

Focal species and study sites. Black-legged kittiwakes nest colonially on sea cliffs throughout much of the circumpolar north. Kittiwakes are monogamous and both sexes participate in brood rearing. In Alaska, kittiwakes tend to lay 1- or 2-egg clutches and chicks remain in the nest until nearly adult size. Kittiwakes are efficient fliers, forage at considerable distances from the nest (up to $100 \mathrm{~km}$ ), and capture prey at or near the surface (Suryan et al. 2000, Jodice et al. 2003). Major prey in this part of the species' range include pelagic schooling fishes such as Pacific herring Clupea pallasi, Pacific sand lance Ammodytes hexapterus, capelin Mallotus villosus, and, to a lesser extent, juvenile gadids (e.g. walleye pollock Theragra chalcogramma, Pacific tomcod Microgradus proximas), salmonids Oncorhynchus spp., and euphausiids (e.g. Thysanoessa spp.; Roby et al. 2000, Jodice et al. 2006).

We collected data from 1996 through 1999 at 3 colonies in Prince William Sound (PWS) and 3 colonies in Lower Cook Inlet (LCI), Alaska, USA (Fig. 1). The Shoup Bay colony in northeastern PWS supported ca. 7000 breeding pairs of kittiwakes. The marine habitat in this area is characterized by fjords, bays, and inlets. The Eleanor Island colony in central PWS supported ca. 220 breeding pairs of kittiwakes; the surrounding area is characterized by protected bays of larger islands and by open water influences from the northern Gulf of Alaska. The North Icy Bay colony in southwestern PWS supported ca. 1800 breeding pairs of kittiwakes in a marine habitat characterized by fjords, bays, and open water influences from the Gulf. During the study period, the Shoup Bay colony was the fastest growing colony in PWS, the North Icy Bay colony increased in population size but at a much slower annual rate (less than half that of Shoup Bay), and the Eleanor Island colony remained fairly stable (Suryan \& Irons 2001).

The Gull Island colony in southeastern LCI supported ca. 5000 breeding pairs of kittiwakes. The marine habitat immediately surrounding Gull Island is characterized by cold, mixed oceanic water with significant freshwater runoff (Robards et al. 1999). The Chisik Island colony in west-central LCI supported ca. 10000 breeding pairs of kittiwakes; the marine habitat in the Chisik Island area is characterized by stratified, 


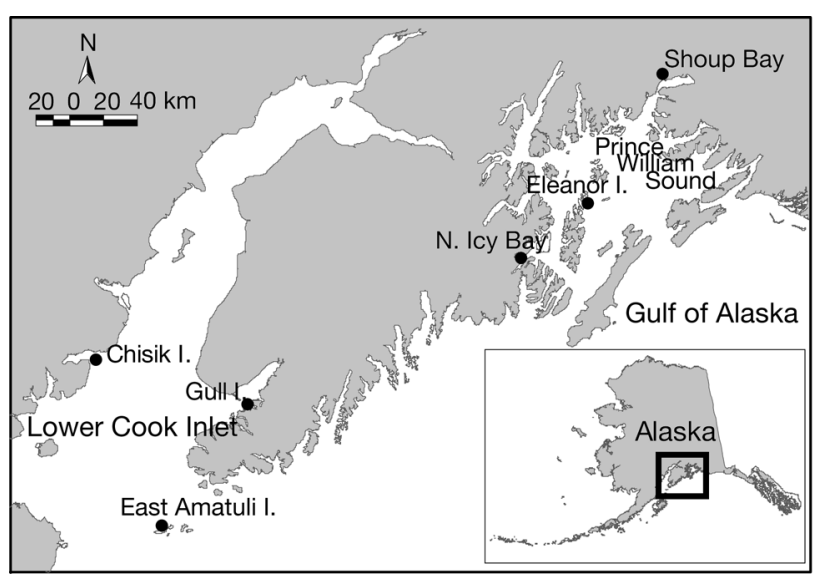

Fig. 1. Rissa tridactyla. Locations of black-legged kittiwake study colonies in Prince William Sound and Lower Cook Inlet, Alaska

relatively warm estuarine waters. The colony at East Amatuli Island, located in the Barren Islands group at the mouth of LCI, supported ca. 6000 breeding pairs of kittiwakes. The marine habitat here is characterized as a transition zone between the northern Gulf of Alaska and the shallow Cook Inlet estuary. The Alaska Coastal Current enters Cook Inlet via the Barren Islands, creating an upwelling zone along the southeastern Cook Inlet shelf (Robards et al. 1999). During the study period, the Gull Island colony was increasing, the Chisik Island colony was declining, and the East Amatuli Island colony was fairly stable (Zador et al. 1997, Robards et al. 1999).

Diet composition. We determined diet composition by collecting regurgitations $(n=918)$ from parent and nestling kittiwakes. All diet samples were stored individually in plastic bags, weighed to the nearest $0.01 \mathrm{~g}$ on electronic balances, labeled, and then frozen. We only included regurgitation samples $\geq 3 \mathrm{~g}$ in our analyses, as smaller samples yielded less reliable information regarding taxonomic composition, meal size, and energy density. We made every effort not to collect samples from the same nestlings or adults more than once. In rare cases where this did occur we allowed for at least 1 wk between samples (Suryan et al.2002).

Species composition of meal samples was determined by K.R.T. at the Institute of Marine Science, University of Alaska Fairbanks. Regurgitations were thawed, reweighed on a top-loading balance $( \pm 0.01 \mathrm{~g})$, and each identifiable prey item measured for standard length $( \pm 1 \mathrm{~mm})$. Taxonomic composition of each sample was determined from gross morphological characteristics of whole or partially digested fish. To estimate standard length of partially digested prey items we (1) used fragments to reconstruct the whole body whenever possible, and (2) used otoliths to estimate standard length using species-specific regression relationships of otolith length vs. standard length (Robards et al. 1999, Stokesbury et al. 1999, Suryan et al. 2000). If a regurgitation consisted mostly of partially digested material, free-floating otoliths were extracted from the sample to determine prey species and estimate the total number of prey items in the sample (2 otoliths of similar size or a left and right matched pair of otoliths were assumed to represent 1 fish). Free-floating otoliths were measured $( \pm 1 \mu \mathrm{m})$ under a microscope using a micrometer. We did not observe any wear to otoliths (all meals samples were relatively fresh and not subjected to substantial digestion) that would have compromised our ability to obtain an accurate measure.

Identifiable prey were categorized into age classes based on documented size-age class relationships. Male capelin $\leq 90 \mathrm{~mm}$ standard length (SL) and female capelin or capelin of unknown sex $\leq 80 \mathrm{~mm}$ were classified as juveniles, reflecting known gender differences in growth rates for this species, while larger-size individuals were classified as adults (Jangaard 1974, Pahlke 1985). Species of nearshore demersal fish (e.g. blennies, sculpins, pricklebacks) $\leq 80 \mathrm{~mm}$ SL and pelagic schooling fishes (i.e. other than capelin) $\leq 100 \mathrm{~mm}$ SL were classified as young-of-the-year (YOY). Larger fish were either older juveniles (e.g. walleye pollock, Pacific tomcod) or included older juveniles and adults (e.g. Pacific sandlance, Pacific herring) and are hereafter referred to as 1+ fish (Smoker \& Pearcy 1970, Dick \& Warner 1982, Hatch \& Sanger 1992).

The above procedure provided the following data for each regurgitation sample: type (whole or random), total mass (g), taxonomic composition by mass (\%), mass ( $g$ ) of each prey species, and mass ( $g$ ) of each age class within each prey species. These variables were then used to quantify diet composition by calculating the proportion of the total collected biomass of regurgitation samples from a colony-year that consisted of each prey type (species and age class).

Delivery rates and their component metrics. We measured the number, mass, and energy density of meals delivered by parents and used these data to estimate the daily rates of biomass and energy provisioning to nests. We measured meal delivery rates (MDR $; \mathrm{n}=545$ nest days) to nestlings (meals nest ${ }^{-1} \mathrm{~d}^{-1}$ ) by observing clustered groups of active nests (or, at the Barren Islands, by reviewing video tapes which, during 1996 and 1997, were compared to direct observations to ensure accuracy; Roseneau et al. 2000). We included different nests each day we conducted MDR watches. When this was not feasible (e.g. some colonies had a limited number of nests that were easily observed), we allowed $7 \mathrm{~d}$ to elapse between watches 
at the same nest (Suryan et al. 2002). MDR watches ranged from 10 to $21 \mathrm{~h}$ among all colonies and years $($ mean $=18.0 \pm 0.08 \mathrm{~h}$, mode $=18 \mathrm{~h})$. To scale all meal delivery data to the rate of meals nest ${ }^{-1} \mathrm{~d}^{-1}$, we multiplied the per hour MDR for each nest watch with the modal watch duration of $18 \mathrm{~h}$. Parental feedings do occur at night but are rare. Therefore, our measures of MDR are likely only slight underestimates of the actual meal delivery rate experienced by nestlings in a $24 \mathrm{~h}$ period.

We used $t$-tests to determine if there were significant differences in MDRs between 1- and 2-chick broods for each colony-year. Where differences existed, we calculated an adjusted meal delivery rate (aMDR) for each colony based on the difference in MDR between 1- and 2-chick broods and mean brood size at fledging for that colony-year:

$$
\begin{gathered}
\mathrm{aMDR}=\mathrm{MDR} 1 \mathrm{a}+\{\mathrm{MDR} 1 \mathrm{a} \times[\% \operatorname{diff} \times(\text { brood size at } \\
\text { fledging }-1)]\}
\end{gathered}
$$

where MDR1a = mean MDR for 1-chick broods and $\%$ diff $=$ the percent difference between the mean MDR for 1- and 2-chick broods. We then calculated the mean aMDR from all broods and present that as the MDR for each colony-year.

Meal size was determined from 918 regurgitations collected from nestlings and adults. We defined 2 types of samples. Whole meal samples $(\mathrm{n}=212)$ were defined as regurgitations collected from nestlings immediately following an observed feeding. These nestlings were encouraged to regurgitate the entire feeding, and thus the entire meal was likely to have been collected. We considered the mass of whole meal samples to be the best estimate of nestling meal size because these samples were recovered immediately after adults returned to the nest and fed their young. Random meal samples were defined as any regurgitation from an adult $(\mathrm{n}=255)$ or a nestling $(\mathrm{n}=451)$, where the probability of collecting an entire meal could not be established. These were collected during routine handling of adults and chicks but the probability of collecting an entire meal could not be established.

The mean $( \pm 1 \mathrm{SD})$ mass of random meal samples, when pooled among all colonies and years (18.1 \pm $0.48 \mathrm{~g}$ ), was less than the mean mass of whole meal samples $\left(25.0 \pm 1.1 \mathrm{~g}_{;} t_{294}=5.7, \mathrm{p}<0.0001\right)$. Therefore, we adjusted the mass of random meal samples to make them comparable to whole meal samples. First we compared the masses of random meal samples collected from adults $($ mean $=19.3 \pm 0.82 \mathrm{~g})$ to random meal samples collected from chicks (mean $=17.4 \pm$ $0.59 \mathrm{~g}$ ) and found there was no difference when data were pooled among all colony-years $(p>0.1)$. Therefore, we used 1 adjustment factor for all random meal samples. We calculated the difference in mean meal mass between random and whole samples separately for any colony-year, using at least 15 samples of both meal types ( $\mathrm{n}=5$ colony-years). Based on data from these sites, the adjustment factor for random meals was 1.35 (i.e. mass $_{\text {whole meal }}=$ mass $_{\text {random meal }} \times 1.35$ ). Meal mass was then estimated for each colony-year as the average mass of all whole chick meal samples ( $n=8$ colony-years) or the average mass of whole meal samples and adjusted random meal samples where a sufficient number of whole meals was not available $(\mathrm{n}=12$ colony-years). All samples represent fresh meals, were collected either from chicks aged between 10 and $30 \mathrm{~d}$ or from parents raising chicks of that age, and were collected throughout each colony.

Proximate composition analysis of all samples was conducted in the laboratory of D.D.R. under the supervision of P.G.R.J. and J.A.A. Details of laboratory procedures followed Anthony et al. (2000). The calculation of energy density for kittiwake meals at each colony during each year then followed a process similar to that used for the calculation of average meal size (i.e. we standardized energy density among meal types). We reasoned that meals collected directly from adults were a better indicator of nestling energy intake compared to meals collected from nestlings because the former were fresher (i.e. less opportunity for digestion, differential assimilation, or hydration). We did not detect a difference in energy density between whole and random meal samples collected from nestlings (Mann-Whitney $U$-test, p = 0.13). We did, however, detect a difference in energy density between meals collected from adults and chicks $(p=0.02)$ when we pooled energy density values across all sites and years that contained sufficient numbers of meal samples from both adults and chicks (i.e. $\geq 15$ of each). On average, the energy density of adult meals was 1.078 times that of chick meals. We adjusted energy density of meal samples from chicks to make them comparable to energy density of meal samples from adults as (energy density $_{\text {adult meal }}=$ energy density chick meal $\left.\times 1.078\right)$. As with meal size, energy density was then calculated for each colony and year as the mean value from all samples. Standardizing energy density values based upon meal samples from adults required that we calculate an adjustment factor for only 4 colony-years.

We estimated a biomass provisioning rate $\left(\mathrm{BPR}_{i}\right.$ $g$ nest $^{-1} \mathrm{~d}^{-1}$ ) and energy provisioning rate $\left(E P R_{i}\right.$ kJ nest ${ }^{-1} \mathrm{~d}^{-1}$ ) for each colony-year. BPR was calculated as the product of mean meal delivery rate (meals $\mathrm{d}^{-1}$ ) and mean meal size $(\mathrm{g})$, while EPR is a product of mean meal delivery rate, mean meal size, and mean energy density of the meal $\left(\mathrm{kJ} \mathrm{g}^{-1}\right)$. We estimated a measure of variance for each of these single-point estimates by incorporating the variability inherent in each of the 
component metrics. We did this by creating a simulation model that randomly selected a data point from each of the component metrics specific to data collected for a given colony-year, multiplied them to get an estimate of BPR and EPR, and then calculated the SD from 1000 runs of the model.

The component data used to calculate BPR and EPR were collected from kittiwake broods aged between 10 and $32 \mathrm{~d}$ posthatch and always collected from throughout the entire colony to allow for complete representation of intracolony variability. The corrections applied to the component data were done so across all colonies and years and their use does not result in any particular bias among colonies or years. Therefore estimates of provisioning rates and comparisons of component data among colonies and years are not biased. Furthermore, due to the complexity of collecting data from 6 colonies over multiple years, we developed and followed specific data collection protocols for each aspect of the field research and trained field technicians each year in their use.

Reproductive success. Measures of kittiwake productivity (chicks fledged per nest structure) were obtained from observations of nests within predefined productivity plots ( $\mathrm{n}=311$ for all colony-years). We selected productivity plots from throughout the entire colony at the start of the study. All nests were included in each plot even if they were started after the median laying date. This ensures that data were not biased by any relationship between productivity and laying date. We used the same set of plots in all years at each colony. If plots or observation points were lost for any reason, new plots were added at the beginning of the breeding season during the laying period. We measured productivity by regularly recording the status of

Table 1. Rissa tridactyla. Generalized linear models used in a model selection process to analyze productivity of blacklegged kittiwakes from 6 colonies in the northern Gulf of Alaska from 1996 to 1999

\begin{tabular}{ll}
$\begin{array}{l}\text { Model } \\
\text { number }\end{array}$ & \multicolumn{1}{c}{ Parameters } \\
\hline 1 & Meal delivery rate, meal size, energy density \\
2 & Meal delivery rate, meal size \\
3 & Meal delivery rate, energy density \\
4 & Meal size, energy density \\
5 & Meal size \\
6 & Meal delivery rate \\
7 & Energy density \\
8 & Region (Prince William Sound, Lower Cook Inlet) \\
9 & Region, year, region $\times$ year \\
10 & Colony \\
11 & Colony, year (colony $\times$ year not included due to \\
& degrees of freedom limitation)
\end{tabular}

each nest in the productivity plots (ca. every $3 \mathrm{~d}$ from the start of egg laying until most nestlings had fledged). Nests were treated as subsamples within a plot. We calculated the average productivity for each plot as the mean number of chicks fledged per nesting structure. Colony averages were calculated as the average productivity of all plots.

Statistical analyses. We used a suite of 11 generalized linear models (Table 1) along with a model selection approach based on the Akaike information criteria (AIC; Burnham \& Anderson 1998) to quantify the effects of diet parameters, region, colony, and year on kittiwake productivity (data from East Amatuli Island 1999 were identified as outliers based on regression diagnostics and omitted from this analysis; see also Piatt 2003). Analytical steps followed those described in Jodice et al. (2002). For the model selection steps we used the AIC statistic corrected for small sample size $\left(\mathrm{AIC}_{\mathrm{C}}\right)$.

Means and regression coefficients are reported as \pm 1 SE. Data measured as proportions were transformed with the arcsine transformation. Other variables were transformed as needed and transformations are noted along with results. Means presented are untransformed data. All analyses were conducted using SAS 9.0 (2002).

\section{RESULTS}

\section{Reproductive performance}

Productivity (Fig. 2) varied significantly with the interaction of colony and year (colony $\times$ year ANOVA $\left.F_{15,287}=13.7, \mathrm{p}<0.0001\right)$. Temporal trends in productivity were not consistent among colonies even within regions (Fig. 2). Colony-wide failures in productivity (i.e. <0.1 young fledged per nest) occurred during at least $1 \mathrm{yr}$ at all colonies except Gull Island. At Eleanor Island in 1998, colony failure was caused by predation (Suryan et al. 2006). Productivity at Chisik Island never surpassed 0.05 young fledged per nest.

\section{Diet composition}

The combined mass of just 3 prey types (Pacific herring, sand lance, and capelin) comprised ca. $81 \%$ of the total biomass in the diet (Table 2). Pacific herring was the most common prey type at colonies in PWS, while sand lance comprised the majority of the diet for colonies in LCI (Table 2). Pacific herring, sand lance, and capelin are characterized by higher lipid content compared to all other prey types identified in the diet (Anthony et al. 2000). The proportion of the diet comprised of these 3 high-lipid prey types differed among 


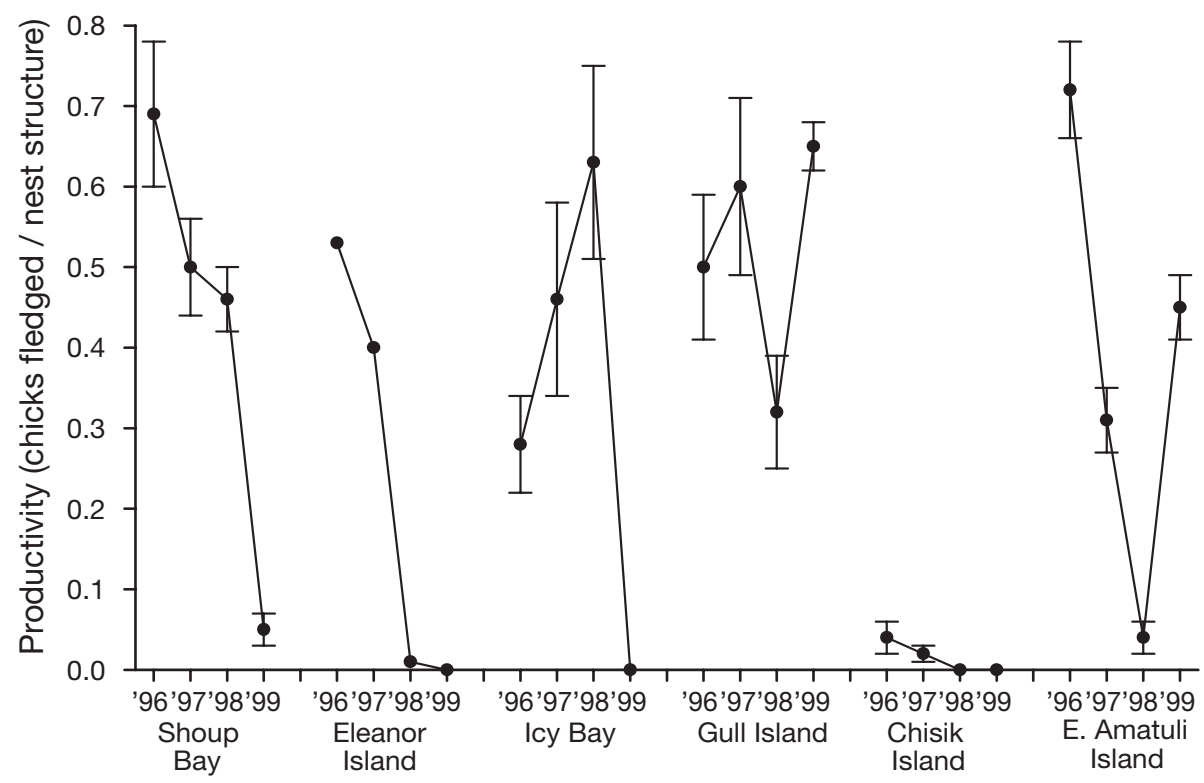

Fig. 2. Rissa tridactyla. Mean $( \pm \mathrm{SE})$ annual productivity (nestlings fledged per nest structure) of black-legged kittiwakes at 6 study colonies in the northern Gulf of Alaska, May to August 1996 to 1999. Error bars are not shown for productivity at the Eleanor Island colony because that measure represented a complete colony census

the 6 colonies $\left(F_{5,12}=4.1, \mathrm{p}=0.02\right.$; Table 3$)$ but did not differ among years $\left(F_{3,12}=2.3, \mathrm{p}=0.13\right)$. There was a higher proportion of the high-lipid prey types in the diet of kittiwakes at Gull Island compared to those at Shoup Bay and Chisik Island.

Differences in the proportion of each of the highlipid prey types in the diets of kittiwakes also occurred among colonies when data were pooled among years $\left(F_{5,16}>3.8, \mathrm{p} \leq 0.02\right.$ for each of the 3 high-lipid prey types; Fig. 3A-C). Sand lance was more abundant and

Table 2. Rissa tridactyla. Taxonomic composition of 918 regurgitations collected from black-legged kittiwake adults and nestlings at 6 colonies in the northern Gulf of Alaska from 1996 to 1999. Values reported are proportion of total biomass $(18.1 \mathrm{~kg})$ collected. $\mathrm{n}=$ number of meals collected. PWS: Prince William Sound; LCI: Lower Cook Inlet

\begin{tabular}{|c|c|c|c|}
\hline Prey type & $\begin{array}{c}\text { PWS } \\
\text { colonies } \\
(\mathrm{n}=585)\end{array}$ & $\begin{array}{c}\text { LCI } \\
\text { colonies } \\
(\mathrm{n}=333)\end{array}$ & $\begin{array}{c}\text { All colonies } \\
\text { combined } \\
(\mathrm{n}=918)\end{array}$ \\
\hline Pacific herring Clupea pallasi & 47.1 & 7.2 & 34.9 \\
\hline Sand lance Ammodytes hexapterus & 20.3 & 60.4 & 32.5 \\
\hline Capelin Mallotus villosus & 9.3 & 22.0 & 13.4 \\
\hline Offal $^{\mathrm{a}}$ & 4.7 & 1.0 & 3.5 \\
\hline Salmonids Oncorhynchus spp. ${ }^{\mathrm{b}}$ & 3.9 & 0.6 & 2.6 \\
\hline Smelts Osmeridae spp. & 1.0 & 2.8 & 2.0 \\
\hline Juvenile Gadidae spp. & 0.5 & 1.0 & 1.1 \\
\hline Euphausiid spp. & 1.5 & 3.3 & 0.9 \\
\hline All other types & 11.7 & 1.7 & 9.1 \\
\hline
\end{tabular}

annually less variable in the diet at Gull Island compared to the 3 PWS colonies (Fig. 3A). Herring was more prevalent in the diets at the Shoup and North Icy Bay colonies compared to the 3 LCI colonies (Fig. 3B). Capelin was most prevalent and least variable in the diet at the East Amatuli Island colony and least prevalent at the Shoup Bay and Gull Island colonies (Fig. $3 C)$. There was no difference in the proportion of juvenile gadids in the diet among colonies ( $p>0.10)$; the mean proportion of juvenile gadids in the diet of kittiwakes was $0.7 \pm 0.003 \%$.

We observed interannual shifts in diet composition within colonies that reflected changes in both the taxonomic composition of the diet and the age distribution within prey types (Fig. 4). Coincidental shifts in the species composition or age distribution of prey types among colonies were more common in PWS compared to LCI. For example, the proportion of herring in kittiwake diets declined from 1996 to 1997 at all 3 PWS colonies. Similarly, a decrease in YOY sand lance and an increase in 1+ herring occurred between 1997 and 1998 at both the Shoup Bay and North Icy Bay colonies. The only diet shift that we observed concurrently among colonies in LCI occurred between 1997 and 1998, when the proportion of sand lance declined and the age structure of sand lance shifted from predominantly YOY in 1997 to 1+ in 1998 at all 3 colonies (Fig. 4). 
Table 3. Rissa tridactyla. Mean ( $\pm \mathrm{SE}$; untransformed) proportion of diet biomass of black-legged kittiwakes at 6 study colonies in the northern Gulf of Alaska that consisted of Pacific herring, sand lance, and capelin combined (i.e. the 3 most common prey types in the diet). Diet biomass was determined by analysis of regurgitated meals collected from adults and nestlings from 1996 to 1999. Colonies sharing any letters are not significantly different (Bonferroni $p>0.05$ )

\begin{tabular}{|cccccc|}
\hline \multicolumn{4}{|c}{ Prince William Sound } & \multicolumn{3}{c|}{ Lower Cook Inlet } \\
$\begin{array}{c}\text { Shoup } \\
\text { Bay }\end{array}$ & $\begin{array}{c}\text { Eleanor } \\
\text { Island }\end{array}$ & $\begin{array}{c}\text { North Icy } \\
\text { Bay }\end{array}$ & $\begin{array}{c}\text { Gull } \\
\text { Island }\end{array}$ & $\begin{array}{c}\text { Chisik } \\
\text { Island }\end{array}$ & $\begin{array}{c}\text { East Amatuli } \\
\text { Island }\end{array}$ \\
\hline $\begin{array}{c}0.77 \pm 0.05 \\
\text { B }\end{array}$ & $\begin{array}{c}0.87 \pm 0.06 \\
\text { AB }\end{array}$ & $\begin{array}{c}0.91 \pm 0.02 \\
\mathrm{AB}\end{array}$ & $\begin{array}{c}0.94 \pm 0.02 \\
0.74 \pm 0.05\end{array}$ & $\begin{array}{c}0.83 \pm 0.04 \\
\mathrm{AB}\end{array}$ \\
\hline
\end{tabular}

Kittiwake nestlings at Shoup Bay and East Amatuli Island appeared to experience the highest interannual variability in BPR (Table 5). Energy provisioning rates ranged from a low of $117 \mathrm{~kJ}$ nest $^{-1} \mathrm{~d}^{-1}$ at Chisik Island in 1996 to a high of $579 \mathrm{~kJ}$ nest ${ }^{-1} \mathrm{~d}^{-1}$ at Shoup Bay in 1996 (Table 5). The significant difference we observed in EPRs among colonies $\left(F_{5,10}=6.1, \mathrm{p}=\right.$ 0.007 ) was due entirely to the low EPRs at Chisik Island. Within each colony, interannual variability in EPRs was greatest at Shoup Bay and least at

\section{Meal delivery rate, meal size, and energy density}

Meal delivery rates varied with the interaction of colony and year $\left(F_{10,525}=3.9, \mathrm{p}<0.0001\right.$, ANOVA on ranked values). Delivery rates were consistently low at Chisik Island and displayed high interannual variability at East Amatuli Island (Table 4). The CV for meal delivery rates from all nest days was $48.7 \%$.

Mean meal size (Table 4 ) differed by colony (individual factor $F_{5,913}=6.6, \mathrm{p}<0.0001$; log transformed) and year (individual factor $F_{3,913}=5.8, p=0.0007$; log transformed). Meal size was larger at Shoup Bay (28.1 \pm $0.9 \mathrm{~g})$ compared to East Amatuli $(22.7 \pm 1.2 \mathrm{~g})$, Eleanor $(21.7 \pm 1.7 \mathrm{~g})$ and Chisik Islands $(16.0 \pm 1.9 \mathrm{~g})$ and was larger in $1996(27.1 \pm 0.8 \mathrm{~g})$ compared to 1997 (23.8 \pm $1.3 \mathrm{~g})$ and $1999(20.2 \pm 1.2 \mathrm{~g})$. The $\mathrm{CV}$ for meal size from all meals was $69 \%$. The mean meal size from all colonies and years $(25.3 \pm 0.6 \mathrm{~g})$ was ca. $7 \%$ of estimated adult body mass (ca. $375 \mathrm{~g}$ ) for kittiwakes at these colonies.

Mean energy density of meals (Table 4) varied by colony $\left(F_{5,913}=10.7, \mathrm{p}<0.0001\right.$; $\log$ transformed $)$ but not by year $\left(F_{3,913}=1.6, \mathrm{p}=0.2 ; \log\right.$ transformed). Pooling data among years within colonies, we found that energy density of meals was greater at Shoup Bay $(5.1 \pm 0.08 \mathrm{~kJ})$ compared to Eleanor Island $(4.5 \pm$ $0.09 \mathrm{~kJ})$, North Icy Bay $(4.4 \pm 0.11 \mathrm{~kJ})$, and East Amatuli Island $(4.2 \pm 0.07 \mathrm{~kJ})$, while energy density of meals from Gull Island $(4.7 \pm 0.09 \mathrm{~kJ})$ was greater than from East Amatuli Island. The CV for energy density among all meals was $29 \%$.

When data were analyzed across all colonies and years (i.e. summary data from Table 4), we found no correlation among meal delivery rate, meal size, and energy density ( $r<0.20$ for each pairwise correlation).

The daily rate of biomass provisioning ranged from a low of $29 \mathrm{~g} \mathrm{nest}^{-1} \mathrm{~d}^{-1}$ at Chisik Island in 1996 to a high of $114 \mathrm{~g} \mathrm{nest}^{-1} \mathrm{~d}^{-1}$ at Shoup Bay in 1996 and North Icy Bay in 1998 (Table 5). The significant difference in mean annual BPR among colonies $\left(F_{5,10}=5.4, \mathrm{p}=\right.$ 0.008) was due entirely to the low BPR at Chisik Island.
Gull Island (Table 5). Lack of statistically significant differences between colonies whose mean BPRs or
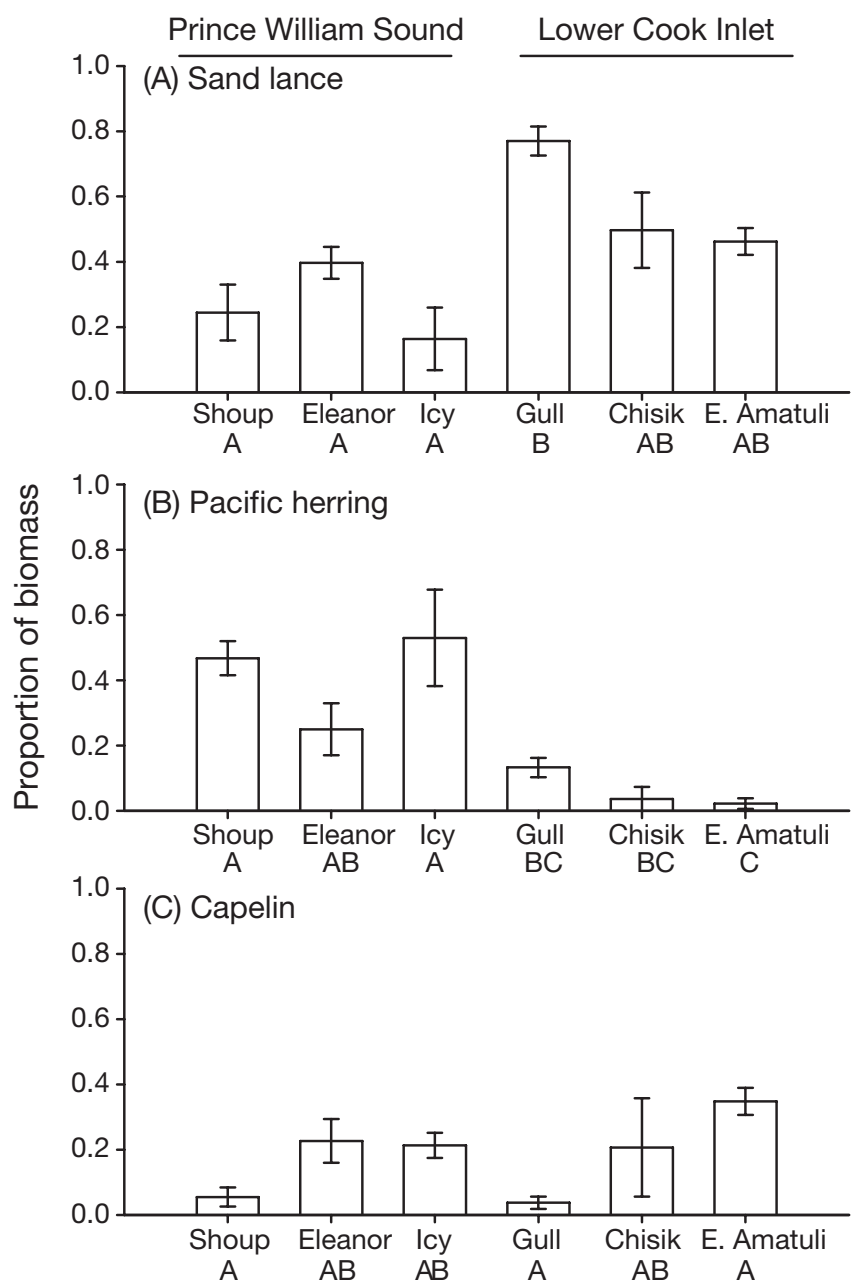

Fig. 3. Rissa tridactyla. Mean $( \pm \mathrm{SE})$ annual proportion of $(\mathrm{A})$ sand lance, (B) Pacific herring, and (C) capelin in diets of black-legged kittiwakes from 6 study colonies in the northern Gulf of Alaska, as determined by analysis of food regurgitations from nestlings and adults, May-August 1996 to 1999. Categories sharing identical letters are not significantly different $(p>0.1)$ 


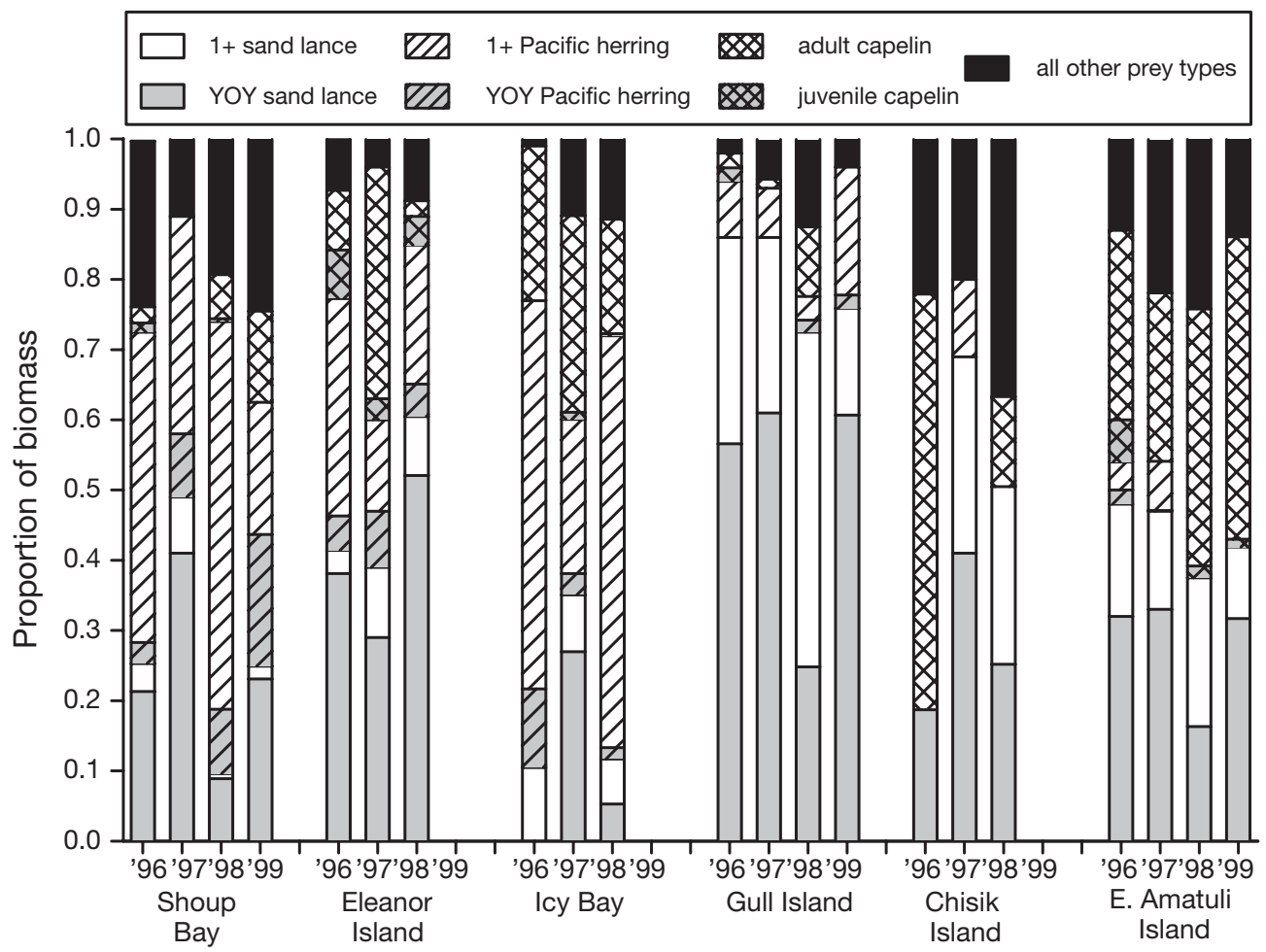

Fig. 4. Rissa tridactyla. Proportion of total biomass and age structure of sand lance, Pacific herring, and capelin in diets of blacklegged kittiwakes from 6 study colonies in the northern Gulf of Alaska, as determined by analysis of food regurgitations from nestlings and adults, May to August 1996 to 1999. YOY = young-of-the-year, $1+=1 \mathrm{yr}$ old or older fish. Data from years of colony failures are not shown, as a sufficient number of samples were not available for determination of diet

EPRs differed by as much as $25 \%$ was likely due to low power associated with only having a single provisioning rate estimate for each colony-year.

\section{Diet parameters and their relationship to productivity}

We examined the extent to which productivity was related to meal delivery rate, meal size, and energy density of prey, region, colony, and year. We used a model selection approach and assessed the fit of 11 models to the productivity data from each colony-year (Table 1). The model that best explained the variability in productivity included meal delivery rate and meal size (i.e. the biomass provisioning rate) and was 2.1 times more likely (ratio of $\mathrm{AIC}_{\mathrm{c}}$ weights for model 2 and model 5; Table 6) to be the best model compared to the next model in the candidate set. The 5 models contained in the $95 \%$ confidence set (i.e. the set of models that would contain the best model in $95 \%$ of cases) each contained some combination of meal delivery rate, meal size, and energy density (Table 6), suggesting each of these 3 parameters has some effect (positive; see below) on kittiwake productivity. The vari- ability in productivity explained by these 5 models ranged from $19 \%$ (model with meal delivery rate only) to $52 \%$ (model with meal delivery rate, meal size, and energy density, i.e. the energy provisioning rate). The coefficient estimates $( \pm 1 \mathrm{SE})$ for the 3 variables contained in the $95 \%$ confidence set were determined using a model averaging approach. All coefficients were positive (meal delivery rate $=0.12 \pm 0.06$, meal size $=0.03 \pm 0.01$, and energy density $=0.14 \pm 0.12$ ) . Colony, region, or year did not appear in any of the models within the $95 \%$ confidence set.

\section{DISCUSSION}

Annual rates of kittiwake productivity vary considerably throughout their range and often in response to prey abundance, although the link to provisioning rates is often unclear (Coulson \& Thomas 1985, Murphy et al. 1991, Danchin 1992, Hamer et al. 1993). Productivity was highly variable among colonies and years during the course of our study. In PWS, productivity at Shoup Bay and Eleanor Island was high in 1996 but progressively lower in subsequent years, while productivity at North Icy Bay followed an oppo- 
Table 4. Rissa tridactyla. Mean $( \pm \mathrm{SE})$ delivery rate (meals per nest day), size (g), and energy density ( $\mathrm{kJ} \mathrm{g}^{-1}$ wet mass) of black-legged kittiwake meals at 6 colonies in the northern Gulf of Alaska from 1996 to 1999. Shoup Bay, Eleanor Island, and North Icy Bay are located in PWS; Gull, Chisik, and East Amatuli islands are located in LCI. na: not available

\begin{tabular}{|c|c|c|c|}
\hline $\begin{array}{l}\text { Location } \\
\text { Year }\end{array}$ & 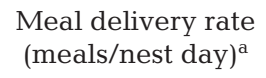 & $\begin{array}{l}\text { Meal } \\
\text { size (g) }\end{array}$ & $\begin{array}{l}\text { Energy density } \\
\left(\mathrm{kJ} \mathrm{g}^{-1} \text { wet mass) }\right.\end{array}$ \\
\hline \multicolumn{4}{|c|}{ Shoup Bay } \\
\hline 1996 & $3.9 \pm 0.23$ & $29.1 \pm 1.22$ & $5.1 \pm 0.11$ \\
\hline 1997 & $2.8 \pm 0.15$ & $28.9 \pm 2.73$ & $5.0 \pm 0.27$ \\
\hline 1998 & $2.7 \pm 0.15$ & $28.2 \pm 1.96$ & $4.9 \pm 0.20$ \\
\hline 1999 & $2.8 \pm 0.23$ & $22.0 \pm 1.88$ & $4.8 \pm 0.20$ \\
\hline \multicolumn{4}{|c|}{ Eleanor Island } \\
\hline 1996 & $4.2 \pm 0.24$ & $23.7 \pm 2.26$ & $4.5 \pm 0.11$ \\
\hline 1997 & $3.8 \pm 0.20$ & $19.2 \pm 2.97$ & $4.8 \pm 0.20$ \\
\hline 1998 & $4.2 \pm 0.27$ & $19.2 \pm 6.12$ & $4.0 \pm 0.29$ \\
\hline $1999^{b}$ & - & - & - \\
\hline \multicolumn{4}{|c|}{ North Icy Bay } \\
\hline 1996 & na & $28.6 \pm 2.45$ & $4.5 \pm 0.15$ \\
\hline 1997 & $4.0 \pm 0.39$ & $25.1 \pm 3.14$ & $4.4 \pm 0.29$ \\
\hline 1998 & $4.8 \pm 0.23$ & $23.7 \pm 2.86$ & $4.3 \pm 0.15$ \\
\hline $1999^{\mathrm{b}}$ & - & - & - \\
\hline \multicolumn{4}{|c|}{ Gull Island } \\
\hline 1996 & $3.5 \pm 0.44$ & $26.6 \pm 2.40$ & $4.5 \pm 0.14$ \\
\hline 1997 & $3.7 \pm 0.26$ & $24.9 \pm 4.32$ & $5.2 \pm 0.23$ \\
\hline 1998 & $4.7 \pm 0.38$ & $22.4 \pm 2.93$ & $4.7 \pm 0.21$ \\
\hline 1999 & $3.9 \pm 0.45$ & $22.4 \pm 3.22$ & $5.0 \pm 0.16$ \\
\hline \multicolumn{4}{|c|}{ Chisik Island } \\
\hline 1996 & $2.0 \pm 0.19$ & $14.3 \pm 5.96$ & $4.1 \pm 0.59$ \\
\hline 1997 & $2.5 \pm 0.33$ & $15.9 \pm 1.96$ & $5.0 \pm 0.36$ \\
\hline $1998^{\mathrm{b}}$ & - & - & - \\
\hline $1999^{\mathrm{b}}$ & - & - & - \\
\hline \multicolumn{4}{|c|}{ East Amatuli Island } \\
\hline 1996 & $4.1 \pm 0.62$ & $23.5 \pm 1.75$ & $4.0 \pm 0.09$ \\
\hline 1997 & $1.7 \pm 0.26$ & $28.8 \pm 2.92$ & $4.2 \pm 0.13$ \\
\hline 1998 & $3.7 \pm 0.34$ & $25.5 \pm 4.36$ & $4.1 \pm 0.17$ \\
\hline 1999 & $2.4 \pm 0.26$ & $17.0 \pm 1.71$ & $4.6 \pm 0.15$ \\
\hline \multicolumn{4}{|c|}{$\begin{array}{l}\text { a Nest days based on deliveries per hour scaled to } 18 \mathrm{~h} \\
\text { besting failure occurred at these colony-years; therefore } \\
\text { too few meals collected to estimate diet parameters }\end{array}$} \\
\hline
\end{tabular}

Table 5. Rissa tridactyla. Annual rate (SD) of food provisioning and energy provisioning to black-legged kittiwake broods at 6 colonies in the northern Gulf of Alaska from 1996 to 1999. Colony-years with total nesting failure (see Table 3) are not presented. Shoup Bay, Eleanor Island, and North Icy Bay are located in PWS; Gull, Chisik, and East Amatuli islands are located in LCI. Note: SD calculated from a resampling model; see 'Materials and methods' for details

\begin{tabular}{|c|c|c|}
\hline $\begin{array}{l}\text { Location } \\
\text { Year }\end{array}$ & $\begin{array}{l}\text { Biomass provisioning } \\
\text { rate }\left(\mathrm{g} \text { nest }^{-1} \mathrm{~d}^{-1}\right)^{\mathrm{a}}\end{array}$ & $\begin{array}{l}\text { Energy provisioning } \\
\text { rate }\left(\mathrm{kJ} \text { nest }{ }^{-1} \mathrm{~d}^{-1}\right)^{\mathrm{b}}\end{array}$ \\
\hline \multicolumn{3}{|c|}{ Shoup Bay } \\
\hline 1996 & $113.5(57.5)$ & 579 (323) \\
\hline 1997 & $80.9(36.7)$ & $404(200)$ \\
\hline 1998 & $76.1(37.6)$ & $373(196)$ \\
\hline 1999 & $61.6(31.1)$ & $296(160)$ \\
\hline \multicolumn{3}{|c|}{ Eleanor Island } \\
\hline 1996 & $99.5(52.8)$ & 448 (239) \\
\hline 1997 & $72.9(42.6)$ & 350 (216) \\
\hline 1998 & $80.6(48.1)$ & $322(204)$ \\
\hline \multicolumn{3}{|c|}{ North Icy Bay } \\
\hline 1997 & $100.4(52.0)$ & 441 (249) \\
\hline 1998 & $113.8(49.3)$ & 489 (221) \\
\hline \multicolumn{3}{|c|}{ Gull Island } \\
\hline 1996 & $93.1(58.1)$ & $419(272)$ \\
\hline 1997 & $92.1(53.1)$ & $479(285)$ \\
\hline 1998 & $105.3(58.9)$ & $495(287)$ \\
\hline 1999 & $87.4(55.4)$ & $437(280)$ \\
\hline \multicolumn{3}{|c|}{ Chisik Island } \\
\hline 1996 & $28.6(18.9)$ & $117(90)$ \\
\hline 1997 & $39.7(17.8)$ & $198(102)$ \\
\hline \multicolumn{3}{|c|}{ East Amatuli Island } \\
\hline 1996 & $96.3(60.2)$ & 385 (247) \\
\hline 1997 & $49.0(28.9)$ & 205 (126) \\
\hline 1998 & $94.3(60.1)$ & $386(255)$ \\
\hline 1999 & $40.8(22.4)$ & $188(118)$ \\
\hline \multicolumn{3}{|c|}{ 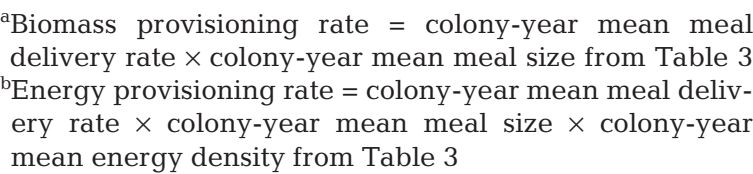 } \\
\hline
\end{tabular}

Table 6. Rissa tridactyla. Model selection statistics from generalized linear modeling of productivity of black-legged kittiwakes from 6 colonies in the northern Gulf of Alaska from 1996 to 1999. Models are ranked from most to least plausible given the data collected and the models tested, but only those models from Table 1 that were included in the $95 \%$ confidence set of models are presented. Model number given in parentheses (see Table 1). Terms specific to the model-selection process are defined in Jodice et al. (2002). $\mathrm{AIC}_{\mathrm{c}}$ : Akaike information criteria corrected for small sample size

\begin{tabular}{|lcccc|}
\hline Model parameters (no.) & $K^{\mathrm{a}}$ & $\Delta \mathrm{AIC}_{\mathrm{c}}$ & $\mathrm{AIC}_{\mathrm{c}}$ weight & $\begin{array}{c}\text { Cumulative sum of } \\
\text { AIC }_{\mathrm{c}} \text { weights }\end{array}$ \\
\hline Meal delivery rate, meal size (2) & & 0.00 & 0.451 & 0.451 \\
Meal size (5) & 3 & 1.49 & 0.214 & 0.666 \\
Meal delivery rate, meal size, energy density (1) & 5 & 2.08 & 0.159 & 0.825 \\
Meal size, energy density (4) & 4 & 3.81 & 0.067 & 0.892 \\
Meal delivery rate (6) & 3 & 4.47 & 0.048 & 0.941 \\
a Number of estimable parameters +1 for intercept + 1 for variance estimator & & \\
\hline
\end{tabular}


site trend. In LCI, productivity at Gull Island was consistently good, productivity at Chisik Island was consistently poor, and productivity at East Amatuli Island was highly variable. Based on longer term data sets, it appears we captured most of the range in productivity among each region (Dragoo et al. 2001).

Variability in kittiwake productivity was best accounted for by the BPR. The EPR was not as likely to represent the best model of those we tested although it was ranked third of 5 among models appearing in the $95 \%$ confidence set and did explain the most variability of any of the models we tested. Both the BRP and EPR were positively related to productivity. We suggest that when poor productivity occurred during the course of this study it was often the result of acute or chronic nutritional stress and that the primary mechanism driving this stress was the quantity of food delivered by the parents. A close examination of the data suggests that prey quality played an important role in kittiwake productivity as well. The lack of a significant effect of colony or year on productivity suggests that attributes such as colony size or population trajectories within colonies were not the primary mechanisms driving productivity. Large colonies appear to fail less regularly than small colonies, however, due in part to their enhanced protection from aerial predators (Ainley et al. 2003, Suryan et al. 2006).

\section{Meal quantity and quality}

In central-place foragers such as marine birds raising nidicolous young, rates of meal delivery are often negatively associated with distance to the prey patch but positively associated with parental energy expenditure, nestling growth rates, and productivity (Ricklefs 1983, Bryant 1991, Suryan et al. 2002, Visser 2002). Therefore, parent seabirds should exhibit higher rates of meal delivery to nestlings when prey patches are nearby to colonies. Black-legged kittiwakes on St. George Island, Alaska, for example, delivered 2.8 meals $\mathrm{d}^{-1}$ to nestlings on average while foraging inside the shelf break, while red-legged kittiwakes Rissa brevirostris at the same colony delivered only 1.5 meals $\mathrm{d}^{-1}$ but foraged at a much greater distance from the colony beyond the shelf-break (Lance \& Roby 1998). Delivery rates, which in our study differed with the interaction of colony and year, also appear to be related to the proximity of prey to the colony and to interannual differences in local forage fish abundance. Kittiwakes at Shoup Bay and Chisik Island, the 2 largest colonies in our study, tended to have the lowest rates of meal delivery and also engaged in foraging trips that covered greater distances compared to kittiwakes at the other 4 colonies (Suryan et al. 2000, Piatt
2003). These longer foraging trips, and hence reduced rates of meal delivery, were necessitated by a lower density of forage fish nearby Shoup Bay and Chisik Island compared to other colonies in the central and southern sections of PWS and LCI (Brown \& Moreland 2000, Ainley et al. 2003, Piatt 2003). The highest productivity recorded at Shoup Bay, Eleanor Island, North Icy Bay, and East Amatuli Island coincided with the highest meal delivery rates at those colonies and tended to occur when forage fish were locally abundant (Suryan et al. 2002, Piatt 2003, Jodice et al. 2006).

Meal size can be a difficult parameter to measure accurately in seabirds compared to meal delivery rates and hence it has not received as much attention in relation to productivity. Lance \& Roby (1998) found that, although overall productivity of red- and blacklegged kittiwakes nesting on St. George Island differed, there was no difference in average meal size between the 2 species. During our study, meal size had a positive effect on productivity and was included in the 4 models that best accounted for the variability in productivity. Mean meal size for kittiwakes in this study was, however, only half that reported for kittiwakes feeding nestlings on St. George Island, Alaska, and the variability we observed in meal size was twice as great as the variability in meal size reported there (Lance \& Roby 1998). Furthermore, Ricklefs (1983) estimated that meal sizes across a variety of seabird species averaged 14 to $18 \%$ of adult body mass, far greater than the value we obtained in this study (ca. $7 \%$ ). These results, and the fact that kittiwakes have the ability to provision meals as large as $100 \mathrm{~g}$ to their chicks (Lance \& Roby 1998), suggest that parents during our study were not maximizing meal payload based on their gut capacity, but instead meal payload was a response to the integration of nestling needs, prey quality, and prey availability. For example, chick meals at Chisik Island were consistently small and infrequent yet high in quality. This reflected poor prey abundance within the foraging range of the colony (Piatt 2003) but relatively high prey quality due to high proportions of capelin and sand lance in the diet each year. In contrast, highly variable meal sizes among years at Shoup Bay reflected the high interannual variability of forage fish in that region, where, for example, preferred prey such as herring may be highly abundant in one year but relatively scarce the next (Suryan et al. 2006). It appears that kittiwakes in PWS and LCI were able to fledge young with smaller meals, compared to kittiwakes on St. George Island, for example, because a greater number of meals $\mathrm{d}^{-1}$ were delivered and because these meals were characterized by relatively high energy densities.

In forage fish, energy density varies among species, among age categories within species, among locations 
within species, and over time within species (Anthony et al. 2000, Wanless et al. 2005). Romano (2000) found that kittiwake and tufted puffin Fratercula cirrhata nestlings fed prey characterized by high energy density and high lipid:protein ratios had higher rates of growth, greater fat reserves upon fledging, and greater energy utilization efficiency compared to nestlings fed an equal biomass of low quality prey. Wanless et al. (2005) found that reduced productivity of common guillemots Uria aalge coincided with a decrease in energy density of primary prey. These observations provide strong support for the junk-food hypothesis.

In contrast, our results did not provide strong support for the junk-food hypothesis. Energy density alone was not among the models that best explained the variability in productivity, although the variable did occur in 2 of the 5 models that appeared in the $95 \%$ confidence set. During the course of our study, however, the range in energy density was quite narrow and did not differ among years. This was a reflection of the breadth and structure of kittiwake diets in PWS and LCI. For example, the mean energy density of the 3 primary prey items (herring, sand lance, and capelin) which comprised $81 \%$ of the total diet biomass during our study ranges from 3.7 to $5.8 \mathrm{~kJ} \mathrm{~g}^{-1}$ wet mass and is higher than most other prey items available in the region (Anthony et al. 2000). In comparison, kittiwake diets on Middleton and St. George Islands, Alaska, can include higher proportions of lower quality prey such as sablefish and juvenile gadids (Lance \& Roby 1998, Gill \& Hatch 2002). Energy density for these 2 species ranges only from 2.5 to $3.5 \mathrm{~kJ} \mathrm{~g}^{-1}$ wet mass (Van Pelt et al. 1997 , Anthony et al. 2000). Thus, parent kittiwakes in LCI and PWS rarely foraged on low quality prey during the course of our study.

Our results clearly demonstrate that BPRs strongly affected kittiwake productivity and that diet quality was less important given that, in general, diet quality was never poor during the course of our study. Variability in diet quality still played an important role in productivity, however. We assessed the effect of diet quality with respect to diet quantity on productivity by examining colony-years with productivity that were higher than predicted for a given biomass provisioning rate (i.e. high positive residuals in the regression of productivity on meal size and meal delivery rate). Examples of this scenario include Shoup Bay 1996 and 1997 and Gull Island 1997 and 1999. Diets for these colony-years were characterized by the highest mean energy densities recorded during our study $(\geq 5.0 \mathrm{~kJ}$ $\mathrm{g}^{-1}$ wet mass), suggesting that diet quality had a positive effect on productivity beyond that afforded strictly by diet quantity.

\section{Reproductive performance and diet composition}

For surface-feeding seabirds, food availability is a complex suite of factors that includes the amount, quality, and 3-dimensional location of prey (Cairns 1987). Each of these factors can affect reproductive effort and performance in different ways, and therefore, it is not surprising that we observed substantial variation in annual rates of productivity that were associated with diet composition both within and among colonies and years. Among colonies the differences in diet patterns were driven to a large extent by the proximity of prey to kittiwake breeding colonies and this appears to form the foundation for the links between reproductive success, provisioning rates, and prey availability (i.e. prey location and abundance). For example, sand lance were relatively abundant along the eastern shore of LCI near Kachemak Bay within 1 to $30 \mathrm{~km}$ of the Gull Island colony during the course of our study (Robards et al. 1999, Piatt 2003), and they dominated the diets of kittiwakes at Gull Island in all years. Although sand lance are not the largest or most energy-dense prey available to kittiwakes in the region (Anthony et al. 2000), Gull Island kittiwakes maintained relatively consistent levels of provisioning and productivity relative to the other colonies while foraging almost exclusively on this abundant, local food source. BPRs and EPRs at Gull Island were relatively stable among years and always surpassed $85 \mathrm{~g}$ and $400 \mathrm{~kJ}$ nest ${ }^{-1} \mathrm{~d}^{-1}$, respectively. Productivity here also was the least variable of any colony in our study and never was among the lowest rates measured. The year of lowest productivity at Gull Island (1998; productivity at East Amatuli Island also was very low) coincided with reduced food availability throughout LCI early in the breeding season (Piatt 2003).

In contrast to Gull Island, diets at Chisik Island were the most variable among colonies and the abundance of forage fish was consistently poor within the foraging range of these kittiwakes, which typically extended 25 to $50 \mathrm{~km}$ from the colony (Piatt 2003). Poor food availability was reflected by low meal delivery rates, low meal size, low BPRs, and low EPRs resulting in colony failure during all years of the study. Interestingly, poor prey quality was not an issue at Chisik Island; annual estimates of energy density there ranged from 4.0 to $5.1 \mathrm{~kJ} \mathrm{~g}^{-1}$ wet mass.

The remainder of the colonies displayed substantial interannual variability in provisioning rates and reproductive performance. Diet composition tended to vary annually among these colonies as well. For example, Shoup Bay kittiwakes tended to rely on herring more so than other colonies. Herring are most common in the large bays of PWS, but these bays, and hence consistent stocks of herring, tend to not be located near the 
colony. Annual differences in herring abundance within the foraging range of these kittiwakes also were substantial (Brown \& Moreland 2000, Suryan et al. 2000, 2002, Ainley et al. 2003). Furthermore, the relatively large breeding population at the Shoup Bay colony may create a halo effect which further increases the distance at which parent kittiwakes need to forage in relation to the colony (Ainley et al. 2003). This suite of factors resulted in Shoup Bay kittiwakes never exceeding 4.0 meals delivered nest ${ }^{-1} \mathrm{~d}^{-1}$. When herring were locally abundant, however, their large size and high energy density translated to high biomass and energy provisioning rates and consequently some of the highest levels of productivity measured during the course of the study (e.g. 1996).

In comparison, kittiwakes from Eleanor Island relied on sand lance more so than kittiwakes from Shoup Bay. Sand lance occur relatively close to the Eleanor Island colony (Suryan et al. 2000) and hence allowed kittiwakes there to maintain relatively high and consistent rates of meal delivery compared to Shoup Bay. Greater inconsistenty in productivity there, including frequent years of failure, were due primarily to top-down factors such as predation and less so to bottom-up factors associated with prey availability (Suryan et al. 2006). The relative effect of predation, especially at a small colony like Eleanor Island, can be magnified by delays in the arrival of forage fish which in turn can cause extensive laying and hatching failures (e.g. Regehr \& Montevecchi 1997).

Our results provide substantial support for the nutritional stress hypothesis, which posited that a reduction in prey abundance, availability, or quality would result in reduced reproductive success for kittiwakes. Most kittiwake colonies experienced nutritional stress during at least $1 \mathrm{yr}$ of our study, although kittiwakes at Chisik Island experienced chronic nutritional stress. Nutritional stress during the course of our study rarely took the form of poor diet quality (i.e. the junk-food hypothesis). Kittiwake diets at our study colonies tended to be comprised of herring, sand lance, and capelin, all of which were characterized by relatively high levels of energy density. In contrast, the overall availability of prey and the quantity of food provisioned varied substantially. This was evidenced by higher levels of variability in both meal delivery rates and meal sizes compared to energy density. The predominance of high-energy prey items available to kittiwakes in LCI and PWS thus set the context for many of the patterns we observed. Within both regions, parent kittiwakes appeared to select prey that were energy-dense and that optimized their ability to provide frequent and/or large meals to nestlings. Additional investigations of nutritional stress in seabirds should be undertaken especially where diet diversity (and hence energy density values) may be greater than what we recorded. Such a scenario may present a more striking comparison of the response of reproductive performance to variability in diet quality.

Acknowledgements. We acknowledge J. Benson, T. Sauer, J. Ryder, M. Blanding, S. Zuniga, and dozens of other technicians for their assistance in the field. We thank D. C. Duffy, B. A. Wright, and the Alaska Maritime National Wildlife Refuge for overall project assistance and logistical support. This research was supported in part by a research grant from the National Oceanographic and Atmospheric Administration (BAA-95118) to D.D.R. as part of the Alaska Predator Ecosystem Experiment (APEX) research project and the Exxon Valdez Oil Spill Trustee Council Restoration Program. The experimental protocol was approved by the Institutional Animal Care and Use Committee at Oregon State University. The views expressed in this paper are those of the authors and do not necessarily reflect those of the Exxon Valdez Oil Spill Trustee Council. Oregon State University, The Oregon Department of Fish and Wildlife, and The US Geological Survey support the Oregon Cooperative Fish and Wildlife Research Unit. Clemson University, The South Carolina Department of Natural Resources, and The US Geological Survey support the South Carolina Cooperative Fish and Wildlife Research Unit.

\section{LITERATURE CITED}

Ainley DG, Ford RG, Brown ED, Suryan RM, Irons DB (2003) Prey resources, competition, and geographic structure of kittiwake colonies in Prince William Sound. Ecology 84: 709-723

Anthony JA, Roby DD, Turco KR (2000) Lipid content and energy density of forage fishes from the northern Gulf of Alaska. J Exp Mar Biol Ecol 248:53-78

Ashmole NP (1971) Seabird ecology and the marine environment. In: Farner DS, King JR (eds) Avian biology, Vol 1. Academic Press, New York, p 224-286

Brodmann PA, Reyer HU, Bollmann K, Schlapfer AR, Rauter C (1997) The importance of food quantity and quality for reproductive performance in alpine water pipits (Anthus spinoletta). Oecologia 109:200-208

Brown ED, Moreland SM (2000) Ecological factors affecting the distribution and abundance of forage fish in Prince William Sound, Alaska; an APEX synthesis product. In: Wright BA, Duffy DC (eds) APEX project: Alaska predator ecosystem experiment in Prince William Sound and the Gulf of Alaska. Exxon Valdez oil spill restoration project final report (restoration project 00163T). Institute of Marine Science, University of Alaska Fairbanks, Fairbanks, AK

Bryant DM (1991) Constraints on energy expenditure by birds. Acta XX Congr Int Ornithologici 4:1989-2001

Burnham KP, Anderson DR (1998) Model selection and inference: a practical information-theoretic approach. Springer Verlag, New York

Cairns DK (1987) Seabirds as indicators of marine food supplies. Biol Oceanogr 5:261-267

Coulson JC, Thomas CS (1985) Changes in the biology of the Kittiwake (Rissa tridactyla): a 31-year study of a breeding colony. J Anim Ecol 54:9-26

Danchin E (1992) Food shortage as a factor in the 1988 kittiwake Rissa tridactyla breeding failure at Shetland. Ardea 80:93-98 
Dick MH, Warner IM (1982) Pacific sand lance, Ammodytes hexapterus Pallas, in the Kodiak Island group, Alaska. Syesis 15:43-50

Dragoo DE, Byrd GV, Irons DB (2001) Breeding status, population trends and diets of seabirds in Alaska, 2000. US Fish Wildl Serv Rep AMNWR 01/07

Gill VA, Hatch SA (2002) Components of productivity in black-legged kittiwakes (Rissa tridactyla): response to supplemental feeding. J Avian Biol 33:113-126

Hamer KC, Monoghan P, Uttley JD, Walton P, Burns MD (1993) The influence of food supply on the breeding ecology of kittwakes (Rissa tridactyla) in Shetland. Ibis 135: 255-263

Hatch SA, Sanger GA (1992) Puffins as samplers of juvenile pollock and other forgage fish in the Gulf of Alaska. Mar Ecol Prog Ser 80:1-14

Jangaard PM (1974) The capelin (Mallotus villosus): biology, distribution, exploitation, utilization, and composition. Bull Fish Res Board Can 186:147-170

Jodice PGR, Roby DD, Gill VA, Lanctot RB, Hatch SA, Visser GH (2002) Does food availability constrain energy expenditure of black-legged kittiwakes raising young? A supplemental feeding experiment. Can J Zool 80:214-222

Jodice PGR, Roby DD, Suryan RM, Irons DB, Kaufman AM, Turco KR, Visser GH (2003) Variation in energy expenditure among black-legged kittiwakes: effects of activityspecific metabolic rates and activity budgets. Physiol Biochem Zool 76:375-388

Jodice PGR, Roby DD, Suryan RM, Irons DB, Turco KR, Brown ED, Thedinga JF, Visser GH (2006) Increased energy in a seabird in response to higher food abundance. Mar Ecol Prog Ser 306:283-293

Lack D (1968) Ecological adaptations for breeding in birds. Methuen, London

Lance BK, Roby DD (1998) Diet and postnatal growth in redlegged and black-legged kittiwakes: an interspecies comparison. Col Waterbirds 21:375-387

Murphy EC, Springer AM, Roseneau DG (1991) High annual variability in reproductive success of kittiwakes (Rissa tridactyla) at a colony in western Alaska. J Anim Ecol 60: 515-534

Pahlke KA (1985) Life history and distribution of capelin, Mallotus villosus, in Alaskan waters. MSc thesis, University of Alaska, Juneau, AK

Phillips RA, Hamer KC (2000) Growth and provisioning strategies of Northern Fulmars Fulmarus glacielis. Ibis 142:435-445

Piatt JF (2003) Response of seabirds to fluctuations in forage fish density: Can seabirds recover from effects of the Exxon Valdez oil spill? In: JF Piatt (ed) Response of seabirds to fluctuations in forage fish density. Final Report to Exxon Valdez Oil Spill Trustee Council (Restoration Project 00163M) and Minerals Management Service (Alaska OCS Region). Alaska Science Center, US Geological Survey, Anchorage, AK, 132-171

Regehr HM, Montevecchi WA (1997) Interactive effects of food shortage and predation on breeding failure of blacklegged kittiwakes: indirect effects of fisheries activities and implications for indicator species. Mar Ecol Prog Ser 155:249-260

Ricklefs RE (1983) Some considerations on the reproductive energetics of pelagic seabirds. Stud Avian Biol 8:84-94

Robards M, Piatt JF, Rose GA (1999) Maturation, fecundity, and intertidal spawning of Pacific sand lance in the northern Gulf of Alaska. J Fish Biol 54:1050-1068

Roby DD, Jodice PGR, Turco KR (2000) Diet composition, reproductive energetics, and productivity of seabirds damaged by the Exxon Valdez oil spill. Exxon Valdez Oil Spill Restoration Project Final Report (Restoration Project 00163G). USGS-Oregon Cooperative Fish and Wildlife Research Unit, Department of Fisheries and Wildlife, Oregon State University, Corvallis, OR

Romano, MD, Roby DD, Piatt JF, Kitaysky A (2000) Effects of diet on growth and development of nestling seabirds. Exxon Valdez Oil Spill Restoration Project Final Report (Restoration Project 98163N). USGS-Oregon Cooperative Fish and Wildlife Research Unit, Department of Fisheries and Wildlife, Oregon State University, Corvallis, OR

Rosen DAS, Trites AW (2000) Pollock and the decline of Steller sea lions testing the junk-food hypothesis. Can J Zool 78:1243-1250

Roseneau DG, Kettle AB, Byrd GV (2000) Barren Island seabird studies. Exxon Valdez Oil Spill Restoration Project Final Report (Restoration Project 00163J), USFWSAlaska Maritime National Wildlife Refuge, Homer, AK

SAS Institute (2002) The SAS system for Windows. Version 9.00. SAS Institute, Cary, NC

Schmidt-Nielsen K (1997) Animal physiology: adaptation and environment, 5th edn. Cambridge University Press, Cambridge

Smoker W, Pearcy WG (1970) Growth and reproduction of the lanternfish Stenobrachus leucopsarus. J Fish Res Board Can 27:1265-1275

Stokesbury KDE, Foy RJ, Norcross BL (1999) Spatial and temporal variability in juvenile Pacific Herring, Clupea pallasi, growth in Prince William Sound, Alaska. Environ Biol Fish 56:409-418

Suryan RM, Irons DB (2001) Colony and population dynamics of black-legged kittiwakes in a heterogeneous environment. Auk 118:636-649

Suryan RM, Irons DB, Benson J (2000) Prey switching and variable foraging strategies of black-legged kittiwakes and the effect on reproductive success. Condor 102: 374-384

Suryan RM, Irons DB, Kaufman M, Benson J, Jodice PGR, Roby DD, Brown ED (2002) Short-term fluctuations in forage fish availability and the effect on prey selection and brood-rearing in the black-legged kittiwake Rissa tridactyla. Mar Ecol Prog Ser 236:273-287

Suryan RM, Irons DB, Brown ED, Jodice PGR, Roby DD (2006) Site-specific effects on productivity of an upper trophiclevel marine predator: bottom-up, top-down, and mismatch effects on reproduction in a colonial seabird. Prog Oceanogr 68:303-328

Trites AW, Donnelly CP (2003) The decline of Steller sea lions in Alaska: a review of the nutritional stress hypothesis. Mamm Rev 33:3-28

Uttley J, Walton P, Monoghan P, Austin G (1994) The effects of food abundance on breeding performance and adult time budgets of guillemots Uria aalge. Ibis 136:205-213

Van Pelt T, Piatt JF, Lance BK, Roby DD (1997) Proximate composition and energy density of some North Pacific forage fishes. Comp Biochem Physiol 118A:1393-1398

Visser GH (2002) Chick growth and development. In: Schreiber EA, Burger J (eds) Biology of marine birds. CRC Press, Boca Raton, FL, p 439-466

Wanless S, Harris MP, Redman P, Speakman JR (2005) Low energy values of a fish as a probable cause of a major seabird breeding failure in the North Sea. Mar Ecol Prog Ser 294:1-8

Zador SG, Harding A, Piatt JF, Ochikubo L, Nielsen AA (1997) Monitoring populations and productivity of seabirds at colonies in lower Cook Inlet, Alaska, 1995. USGS Final Rep., Minerals Management Service, Anchorage, AK 